\title{
In vitro assay to select rainbow trout with variable resistance/susceptibility to viral haemorrhagic septicaemia virus
}

\author{
Edwige Quillet ${ }^{1, *}$, Michel Dorson ${ }^{2}$, Gérard Aubard ${ }^{1}$, Corinne Torhy ${ }^{2}$ \\ ${ }^{1}$ INRA (Institut National de la Recherche Agronomique), ${ }^{1}$ UR544 Unité de Génétique des Poissons, and \\ ${ }^{2}$ UR892 Unité de Virologie et d'Immunologie Moléculaires, 78350 Jouy-en-Josas, France
}

\begin{abstract}
The merit of a candidate criterion of resistance to viral haemorrhagic septicaemia virus (VHSV) was tested with the view of producing experimental trout progeny with a predictable level of resistance. The criterion, the measure of in vitro viral replication in excised fin tissue (VREFT) was previously developed (Dorson \& Torhy 1993; J Fish Dis 16:403-408). Three experiments were performed, using both ordinary and homozygous doubled-haploid breeders. A set of 48 progeny was tested. Breeders were individually scored for repeated measures of VREFT, and the progeny were tested against VHSV (strain 07-71, serotype 1) through a waterborne challenge $\left(5 \times 10^{4} \mathrm{pfu} \mathrm{ml}^{-1}\right.$ during $2 \mathrm{~h}$ ). Analysis of repeated measures of VREFT revealed the risk of identifying 'false' resistant individuals. The highest value should be considered the most predictive of the resistance status. Survival of progeny ranged from 0 to $100 \%$ according to the group and the experiment. The survival was correlated to the mean VREFT value of the breeders in Expts 1 and 2 ( $R=0.96$ and 0.61 respectively), but not in Expt $3(\mathrm{R}=0.36, \mathrm{~ns})$ where all tested progeny were highly susceptible. Results thus indicate that viral growth in fin tissue is genetically correlated to resistance to waterborne disease and may be used to produce selected progeny, at least at the experimental scale. Possible implications of the relationship between VREFT and resistance for the study of resistance mechanisms are discussed.
\end{abstract}

KEY WORDS: Rainbow trout $\cdot$ VHS $\cdot$ Selection $\cdot$ Resistance $\cdot$ Disease $\cdot$ Oncorhynchus mykiss $\cdot$ Fin Resale or republication not permitted without written consent of the publisher

\section{INTRODUCTION}

Rainbow trout Oncorhynchus mykiss W. is the most important species in continental farming in western and southern Europe. As in other species, intensive farming is hampered by several diseases which are responsible for economical, environmental and ethical concerns. Viral haemorrhagic septicaemia (VHS) is a severe rhabdoviral disease caused by Egtved virus (Jensen 1965). Despite strict sanitary policies (World Organisation for Animal Health [OIE] regulations, www.oie.int/eng/en_index.htm), VHS still causes heavy economical losses in some areas, as outbreaks of the disease usually provoke high mortality and may affect market size fish.

Controlling the disease (i.e. by implementing efficient vaccines; see review by de Kinkelin 1988, Loren- zen \& Lapatra 2005) requires increased and more comprehensive knowledge of the immune pathway of defence mechanisms and the genetic architecture of host-pathogen responses.

The comparison of individuals with opposite diseaserelated phenotypes may be a powerful tool to identify genetic elements and pathways underlying disease susceptibility, as exemplified by the advances in mouse genetics (Peltz \& Usuka 2005).

In fish, the approach has been developed to a far lesser extent. Models for immune-related traits have been studied, such as carp with differential antibody production (Wiegertjes et al. 1996, Bandin et al. 1997) and trout with differential lysozyme activity (Røed et al. 2002) or natural killer-like activity (Zimmerman et al. 2004). Trout with opposite resistances have also been used to investigate the response to 
specific diseases: furonculosis (Hollebecq et al. 1995, Michel \& Hollebecq 1999), infectious pancreatic necrosis virus (IPNV; Ozaki et al. 2001) and infectious haematopoietic necrosis virus (IHNV; Palti et al. 1999, Trobridge et al. 2000, Khoo et al. 2004). The most recent of such studies aimed to detect quantitative trait loci (QTL), which is a first step toward the ultimate identification of the responsible genes and causal mutations.

As regards VHSV, families selected for resistance have been used in trials aiming at identifying factors involved in host response to the virus (Slierendrecht et al. 1993, 1996, 2001).

In fish, chromosome manipulation techniques (mitotic gynogenesis or androgenesis) make it possible to produce fully homozygous doubled-haploid individuals among which the production and detection of individuals with extreme phenotypes may be accelerated. In doubled-haploid populations, additive genetic variance is twice as high as in control populations (Bongers et al. 1997) and heritability is increased (Bijma et al. 1997). Doubled-haploids may also be used to produce clonal progeny (homozygous or heterozygous) in one more generation. Within a clone, individuals share the same genetic background and are histocompatible, which dramatically expands the field of investigation of the immune system. Clones have already been used for this purpose in trout (Ristow et al. 1998, 2000, Boudinot et al. 2001, Bernard et al. 2006).

During the course of investigations on VHS in trout, Dorson \& Torhy (1993a) developed an in vitro assay, termed the viral replication in excised fin tissue (VREFT) value, which measures the ability of fin tissue to support viral replication after in vitro infection. Under experimental conditions, the VREFT value correlates with mean mortality after waterborne experimental disease (Dorson \& Torhy 1993b, Quillet et al. 2001) and low VREFT values are associated with resistance. It thus appears that VREFT values could be considered to be secondary traits for selection of susceptible or resistant individuals.

The aim of the present study was to determine whether the use of VREFT values would be efficient in selecting individual brood fish and producing progeny with a predicted level of resistance for further experimental purposes (genetic and immunological studies). Owing to the reasons explained before, the study was initially designed to select among doubled-haploid breeders. Due to experimental limitations, ordinary breeders were included in a second step. A small-scale field test was also performed to evaluate the utility of the VREFT values for further commercial selection purposes.

\section{MATERIALS AND METHODS}

Brood stock and gamete collection. Rainbow trout brood fish originated from the INRA 'synthetic' strain (Sy), kept at the INRA experimental trout farm (Gournay-sur-Aronde, Oise, France). The farm is free of known viruses and is permanently controlled. Two kinds of parents were used: normal Sy parents and doubled-haploid mito-gynogens (Gm) derived from the same strain. Gm fish were produced according to the procedure described in Diter et al. (1993), i.e. activation of ova by UV-irradiated sperm, followed by a late heat shock $\left(31^{\circ} \mathrm{C}\right.$ for $5 \mathrm{~min}, 220 \mathrm{~min}$ after fertilisation) designed to inhibit the first embryonic mitosis. Males homozygous for a dominant mutation of body colour (golden phenotype) were used as milt donors, and the lack of golden fry in the gynogenetic progeny was an initial control of the efficiency of the irradiation process. Every Gm breeder was ultimately checked for homozygosity using allelic variation at 4 microsatellite markers. Because of the genetic determinism of sex in trout (female homogamety), Gm fish are all females, and some of our subjects therefore had to be sexreversed by early hormonal treatment (Cousin-Gerber et al. 1989) to obtain functional XX males.

Experimental progeny were produced during 3 different winters. Each spawning season, gametes were collected on the farm from mature breeders (abdominal pressure on anaesthetised individuals) and transported on ice to the laboratory for fertilisation to produce experimental groups. Some sex-reversed males did not produce milt. They were sacrificed (lethal dose of 2-phenoxyethanol) and their testes were dissected to collect milt. The resistance status of individual breeders was assessed using the VREFT value as a predictive trait.

Experimental groups. The origin and number of the different groups are detailed in Table 1.

Expt 1 involved Gm parents only. Eight Gm breeders (4 males, 4 females) were mated according to two $2 \times 2$ factorial designs. Because of deleterious effects of homozygosity on reproductive performance (Quillet 1994), survival was quite low in some groups, and only 6 of the 8 heterozygous clones could be kept for further tests. A control group was produced (mixture of ova from 15 Sy females fertilised with a mixture of milt from 12 Sy males).

Expt 2 aimed to produce new experimental progeny and confirming the results recorded in Expt 1. To prevent excessive loss among Gm progeny, normal Sy parents (4 females, 2 males) were added to the $\mathrm{Gm}$ ones (10 females, 5 males). Depending on the number of ova, each Gm or Sy female was mated with 2 to 5 males, according to an incomplete factorial design. Three types of progeny were produced: clones $\left(\mathrm{Cl}_{\text {, }}\right.$ 
Table 1. Number and type of experimental progeny, number and mean weight of individuals challenged with waterborne VHSV and cumulative mortality (\%) recorded in the different experiments. Types of progeny are clones (Cl, i.e. doubled-haploid mitogynogen $[\mathrm{Gm}] \times \mathrm{Gm}$ crosses), hemiclones $(\mathrm{HCl}$, INRA synthetic strain $[\mathrm{Sy}] \times \mathrm{Gm}$ or $\mathrm{Gm} \times \mathrm{Sy}$ crosses), full-sibs (FS, individual Sy $\times$ Sy crosses) and half-sibs (HS, pooled Sy $\times$ individual Sy crosses)

\begin{tabular}{|c|c|c|c|c|c|c|}
\hline \multirow{3}{*}{ Experiment } & \multicolumn{2}{|c|}{ Experimental progeny } & \multirow{3}{*}{ No. of fish group ${ }^{-1}$} & \multirow{3}{*}{$\begin{array}{l}\text { VHSV challenge } \\
\text { Mean weight (g) }\end{array}$} & \multirow{2}{*}{\multicolumn{2}{|c|}{ Cumulative mortality (\%) }} \\
\hline & Type & No. of groups & & & & \\
\hline & & & & & Mean & Range \\
\hline \multirow[t]{2}{*}{ Expt 1} & $\mathrm{Cl}$ & 6 & $25^{\mathrm{a}}$ & $2.2-5.6$ & 74 & $28-100$ \\
\hline & Control & 1 & & 2.45 & 88 & \\
\hline \multirow[t]{4}{*}{ Expt 2} & $\mathrm{Cl}$ & 5 & & & & \\
\hline & $\mathrm{HCl}$ & 16 & 25 & $1.0-5.0$ & 42 & $0-100$ \\
\hline & FS & 3 & & & & \\
\hline & Control & 1 & 25 & 1.9 & 88 & \\
\hline \multirow[t]{2}{*}{ Expt 3} & HS & 15 & 50 & $1.6-2.0$ & 88 & $50-100$ \\
\hline & Control & 1 & 50 & 1.7 & 97 & \\
\hline \multicolumn{7}{|c|}{ a 1 clone with only 20 challenged fish } \\
\hline
\end{tabular}

from $\mathrm{Gm} \times \mathrm{Gm}$ crosses), hemiclones $(\mathrm{HCl}$, from $\mathrm{Gm} \times$ Sy or Sy $\times$ Gm crosses) and full-sib families (FS, from Sy $\times$ Sy crosses). A total of 46 experimental groups were fertilised. Every second Gm female produced no or too few progeny to be used, so that only 24 progeny could be kept for further tests (involving $5 \mathrm{Gm}$ females, $4 \mathrm{Gm}$ males and the 6 Sy parents). A control group was also produced (pool of 10 Sy females crossed with a pool of 10 Sy males).

Expt 3 was designed as a 'field-like' test aimed at selecting male breeders to improve resistance. It involved only Sy parents. Gametes were collected from 15 normal Sy males and 6 Sy females. Eggs from the different females were mixed (equal weight from each), and redistributed into 16 batches. Fifteen batches were individually fertilised with the milt of individual males, so that 15 half-sib families (HS) were produced. The Sy control group was produced by fertilising the last batch with the mixture of sperm from the 15 males.

In all 3 experiments, the eggs were incubated in $10 \times$ $10 \mathrm{~cm}$ incubators in a recirculated rearing unit $\left(10^{\circ} \mathrm{C}\right)$. At the eyed stage, the eggs were disinfected with iodine and transferred to $10 \mathrm{l}$ aquaria supplied with recirculated, dechlorinated tap water (constant $10^{\circ} \mathrm{C}$ ) which was free of pathogens. Fry were fed twice daily (once a day on weekends) with commercial pellets. Under these rearing conditions, fish remain healthy but grow much slower than in commercial farms.

Virus production. VHSV strain 07-71 (serotype 1) isolated from diseased fish from a French trout farm was propagated in epithelioma papulosum cyprini (EPC) cells as described by Dorson et al. (1995). After infection, the cells were incubated at $14^{\circ} \mathrm{C}$ in Stoker's medium buffered at $\mathrm{pH} 7.4$ with $0.16 \mathrm{M}$ Tris- $\mathrm{HCl}$ and supplemented with $2 \%$ foetal calf serum and antibiotics (penicillin $100 \mathrm{IU} \mathrm{ml}^{-1}$, streptomycin $0.1 \mathrm{mg} \mathrm{ml}^{-1}$ and kanamycin $0.1 \mathrm{mg} \mathrm{ml}^{-1}$ ). The virus was harvested when the cytopathic effect was complete.

VREFT values from breeders' excised fins. Rayed fins were clipped from anaesthetised (2-phenoxyethanol) fish.

In Expt 1, a single sampling (anal fin) was performed on each breeder $(n=8)$ at the time of gamete collection. Weights of tissue samples ranged from 38 to $77 \mathrm{mg}$.

In Expt 2, future breeders were individually tagged with internal transponders and were sampled (anal fin) 3 times: during the summer prior to spawning (Sample 1), just after spawning (Sample 2, on an intact area of the same fin) and 9 mo later (Sample 3, same procedure). Due to post-spawning mortalities, some of the 15 breeders that had contributed to the experimental progeny were sampled only twice $(n=6)$ or once $(\mathrm{n}=3)$. The range of fin sample weights was 57 to $96 \mathrm{mg}, 20$ to $62 \mathrm{mg}$ and 41 to $49 \mathrm{mg}$ for Samples 1, 2 and 3 , respectively.

In Expt 3, males were individually tagged and sampled twice: at spawning (Sample 1, anal fin) and 1 yr later (Sample 2, caudal fin, 5 survivors). The range of fin sample weights was 31 to $47 \mathrm{mg}$ for anal fins and 46 to $59 \mathrm{mg}$ for caudal fins. Females were not controlled.

Fin tissues were processed immediately after sampling according to the procedure described by Dorson \& Torhy (1993a): each fin was weighed and immersed for $1 \mathrm{~h}$ in $2 \mathrm{ml}$ of Stoker's medium containing $2 \times 10^{5}$ VHSV pfu ml ${ }^{-1}$ and then rinsed 3 times. They were next incubated for $3 \mathrm{~d}$ at $14^{\circ} \mathrm{C}$ in 6 -well plates. The plates were then frozen at $-80^{\circ} \mathrm{C}$ until virus titration. After thawing, the fins were ground in a mortar and pestle together with the incubation medium, the debris were eliminated by centrifugation and the virus was titrated as follows. Serial 10-fold dilutions of the sam- 
ple were inoculated onto EPC monolayers freshly prepared in 6-well plates (Nunc). After a $1 \mathrm{~h}$ adsorption period, the cells were covered with $2 \mathrm{ml}$ of Stoker's medium containing $0.4 \%$ agarose. After $3 \mathrm{~d}$ at $14^{\circ} \mathrm{C}$, the cells were fixed with $10 \%$ formalin and stained with $1 \%$ crystal-violet. The plaques were then counted. The sensitivity threshold corresponding to $1 \mathrm{pfu} \mathrm{dish}^{-1}$ was $10 \mathrm{pfu} \mathrm{ml}^{-1}$, i.e. approximately $1 \mathrm{pfu}$ $\mathrm{mg}^{-1}$. Therefore, 0 plaques means less than $1 \mathrm{pfu} \mathrm{mg}^{-1}$.

Viral challenges. The VHSV waterborne challenges were performed according to Dorson \& Torhy (1993a) when the fish were 4 to 6 mo old. The day before challenge, all fish in the groups to be challenged were anaesthetised and the desired number of fish was sampled, weighed in bulk and transferred to aquaria in the recirculating unit reserved for the challenge. Fish of extreme sizes (less than $2 \%$ of the total) were eliminated, and the remainder served as non-infected controls. For the challenge, the water supply of the aquaria was stopped and the infected fish were kept for $2 \mathrm{~h}$ in a $5 \times 10^{4}$ pfu $\mathrm{ml}^{-1}$ virus suspension under vigorous aeration. Details about mean weight and numbers of challenged fish are given in Table 1. The level of mortality was monitored daily for $34 \mathrm{~d}$ in Expt 1, $21 \mathrm{~d}$ in Expt 2 and $25 \mathrm{~d}$ in Expt 3.

There was usually no mortality in the non-infected control groups, indicating that disease was the most likely cause of death for challenged fish. Moreover, the kinetics of death and the symptoms observed were characteristic of VHS, with which our laboratory has much experience. Complete diagnostic and reisolation of the virus was performed in the case of late and atypical mortality (especially the so-called nervous form).

Statistical analyses. Resistance of progeny was expressed as cumulative mortality and was calculated for every aquarium as the number of dead fish at the end of the survey period divided by the initial number of infected fish. It is expressed as a percentage in the tables and figures.

Statistical analyses aimed to study (1) the withinindividual correlations between successive measurements of VREFT in Expts 2 and 3 and (2) how the resistance (mortality) of the progeny depended on the VREFT values of individual parents.

As a first step, data were screened using nonparametric methods. In Expts 2 and 3, Spearman's rank correlation coefficient ( $\rho$ ) was used to test the withinindividual correlations between repeated measurements of VREFT. It was also used to test the predictive value of the different VREFT records available for each breeder and to choose the most appropriate one to explain the performance of progenies (i.e. minimum VREFT record, maximum VREFT record or mean of the different records). In Expt 2, the parental data of VREFT tested for correlation were indicated as mini- mum, mean and maximum mid-parent values (arithmetic mean of VREFT values of male and female), and in Expt 3, parental data of VREFT were indicated as minimum, mean and maximum VREFT values of male parents.

As a second step, the relationship between parental VREFT values and resistance of progeny was further investigated using regression analyses (SAS software, SAS Institute). The dependent variable was the mortality of progeny after the challenge, indicated as the angular transformed proportion of dead fish. As the frequency distribution of VREFT values does not fit a normal distribution and is highly skewed to the right (Quillet et al. 2001), and to deal with null values of VREFT, individual VREFT values were $\log (x+1)$-transformed. Only maximum VREFT values were retained when available. Therefore, the data of VREFT used for regression analyses in Expt 2 were indicated as the maximum mid-parent values (arithmetic mean of logtransformed maximum VREFT values of male and female) and maximum male transformed VREFT value for Expt 3. In Expt 1, the data of VREFT were indicated as the single score of mid-parents (arithmetic mean of log-transformed VREFT values of male and female).

In Expt 2, separate regressions using either male or female parent individual maximum transformed VREFT values were also performed. Finally, a model using separate regressions for the Gm or Sy parent maximum transformed VREFT values was also tested in a sub-set of data containing only $\mathrm{HCl}$ groups.

\section{RESULTS}

\section{VREFT values from breeders' excised fins}

Means of the breeders' VREFT values in the different experiments are presented in Table 2. VREFT values ranged from 0 to $5625 \mathrm{pfu} \mathrm{mg}^{-1}$. Correlations between the different VREFT values of individual fish (Expts 2 and 3) exhibited moderate to low values (Spearman's rank correlation coefficient $\rho=0.51$ to 0.67 , Table 3). The correlation was significant $(\mathrm{p}<$ 0.05 ) only between Samples 1 and 2 in Expt 2. Observation of individual records (Fig. 1) showed 3 groups of

Table 2. Means and ranges of the individual absolute VREFT values (pfu $\mathrm{mg}^{-1}$ ) recorded at the first sampling (anal fin) of breeders in the different experiments

\begin{tabular}{|lccc|}
\hline & Expt 1 & Expt 2 & Expt 3 \\
\hline Number of breeders & 8 & 15 & 15 \\
Mean & 613 & 529 & 1633 \\
Range & $0-4190$ & $0-3636$ & $67-5625$ \\
\hline
\end{tabular}


Table 3. Spearman's rank coefficient of correlation $(\rho)$ between successive absolute VREFT values recorded on rayed fins of individual breeders in Expts 2 and 3 (see text for details of the sampling schedule). Values in parentheses are the number of observations. ${ }^{*} \mathrm{p}<0.05$

\begin{tabular}{|c|c|c|c|c|}
\hline & \multicolumn{2}{|c|}{ Sample 2} & \multicolumn{2}{|c|}{ Sample 3} \\
\hline & Expt 2 & Expt 3 & Expt 2 & Expt 3 \\
\hline Sample 1 & $0.66^{*}(11)$ & $0.51(5)$ & $0.56(7)$ & - \\
\hline Sample 2 & & & $0.67(6)$ & - \\
\hline
\end{tabular}

fish: fish with consistently high VREFT values $\left(>100 \mathrm{pfu} \mathrm{mg}^{-1}\right)$, fish with consistently low values $\left(<20 \mathrm{pfu} \mathrm{mg}^{-1}\right)$, and fish having scores ranging to both extremes. At this step, it was therefore difficult to decide which record would give the most accurate description of the resistant/susceptible status of individual brood fish. Thus, 3 values (minimum record, maximum record and mean of available records) were kept for further investigation into the suitability of VREFT as a predictor of the resistance/ susceptibility.

\section{Survival after challenge}

Overall, 48 progeny groups were challenged (respectively 6, 24 and 15 groups for Expts 1 to 3, plus a Sy control group for each experiment). The level of mortality of the Sy controls (more than $80 \%$ ) indicated good efficiency of the challenge process. Mortality in Expts 1 and 2 (88\%) was typical of the values usually recorded in our experimental conditions using the same fish and the same viral strains, while it was particularly high in Expt 3 (97\%).

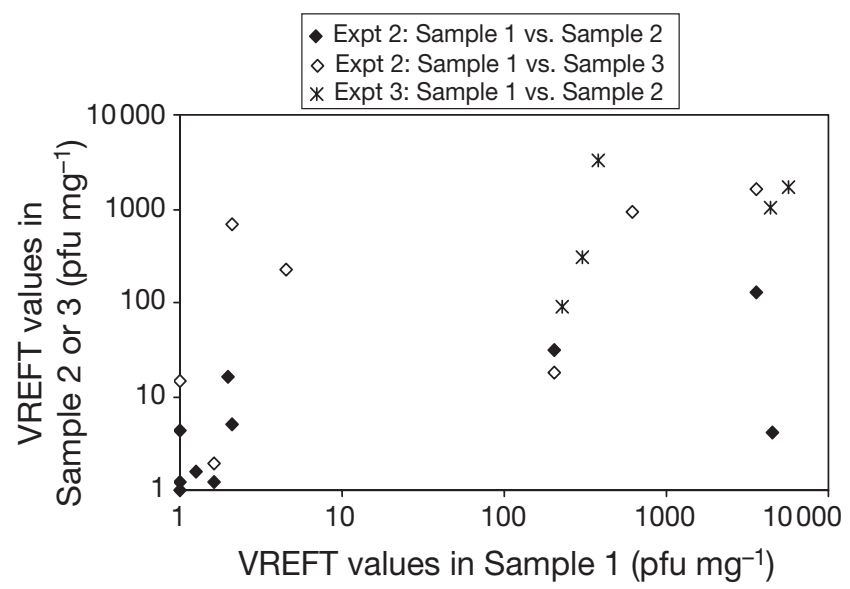

Fig. 1. Successive VREFT values recorded on rayed fins of individual breeders in Expts 2 and 3 (logarithmic scale; details of fin sampling in 'Materials and methods: VREFT values from breeders' excised fins')

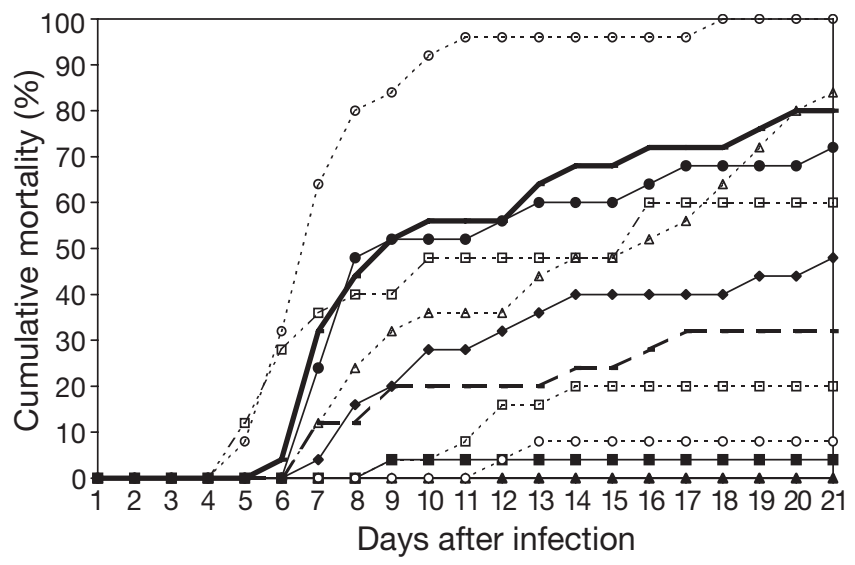

Fig. 2. Examples of cumulative mortality curves recorded in experimental groups of Expt 2. Sy control: thick continuous line; FS group: thick dashed line; $\mathrm{Cl}$ groups: thin dotted lines with open symbols; $\mathrm{HCl}$ groups: thin continuous lines with black symbols

Mean values and the range of cumulative mortality recorded in the experimental groups are summarised in Table 1. Cumulative mortality was highly variable among groups (overall range: 0 to $100 \%$ ). Fig. 2 shows a sample of the observed mortality curves. There was no correlation between the cumulative mortality and the mean weight of groups at the time of the challenge (data not shown).

\section{Correlation between breeders' VREFT values and mortality of the progeny}

The relevance of the different VREFT values of brood fish (minimum, mean or maximum) was tested using either the mid-parent values (Expt 1 or 2) or the male values (Expt 3). When a fish was measured only once, the single value was used as minimum, mean and maximum. Spearman's rank correlation coefficients between mortality of progeny and parental VREFT scores are summarised in Table 4. In Expt 2, correlation using minimum mid-parent values was not

Table 4. Test of the merit of successive measurements of VREFT for individual breeders in predicting the resistant/susceptible status of progeny. Table shows values of Spearman's rank correlation coefficient $(\rho)$ between mortality of the progeny $(\%)$ and the mid-parent VREFT values (Expt 2) or the male parent VREFT values (Expt 3). Calculations were performed for minimum, mean or maximum parental VREFT values (details in 'Statistical analyses'). ${ }^{* *} \mathrm{p}<0.01,{ }^{*} \mathrm{p}<0.05$

\begin{tabular}{|c|c|c|c|c|c|c|}
\hline \multirow[t]{2}{*}{ VREFT value } & \multicolumn{3}{|c|}{ Expt 2} & \multicolumn{3}{|c|}{ Expt 3} \\
\hline & Min & Mean & Max & Min & Mean & Max \\
\hline Number of pairs & & 24 & & & 15 & \\
\hline$\rho$ & 0.32 & $0.52^{*}$ & $0.57^{* *}$ & 0.22 & 0.27 & 0.37 \\
\hline
\end{tabular}


significant. Using mean values increased the correlation, while the highest correlation was observed using maximum values $(\rho=0.57, p<0.01)$ In Expt 3 , similar results were recorded (correlations increasing from minimum to maximum VREFT values), although the correlation was never significant.

Thus, maximum VREFT records tended to provide the most accurate description of the resistant/susceptible status of brood fish and were used for further regression analyses when available (Expts 2 and 3).

Results of regression analyses are presented in Fig. 3. Regression coefficients using the mid-parent VREFT transformed values were significant in Expts 1 and 2, and the goodness of fit of the model was medium to high $\left(\mathrm{R}^{2}=0.93\right.$ and 0.38 , respectively), while in Expt 3, the regression coefficient using male parent transformed values was positive but not significant $\left(\mathrm{R}^{2}=0.13\right)$.

In Expt 2, separate regression coefficients were calculated for each parent. Regression coefficients were significant for both parents $(b=0.16, p=0.006$ for female VREFT value, and $b=0.15, p=0.03$ for male VREFT value), and the overall goodness of fit was of the same magnitude as the one using mid-parent values only (data not shown).

In order to test whether Gm and Sy parents contributed differently to the explanatory value of the model, regression analysis was performed using only the $\mathrm{HCl}$ groups of Expt 2. The goodness of fit of the model was quite high $\left(R^{2}=0.54, p=0.007\right)$. The separate regression coefficients were similar $\left(b_{\mathrm{Sy}}=b_{\mathrm{Gm}}=\right.$ $0.18, \mathrm{p}=0.01$ and $\mathrm{p}=0.06$, respectively) and did

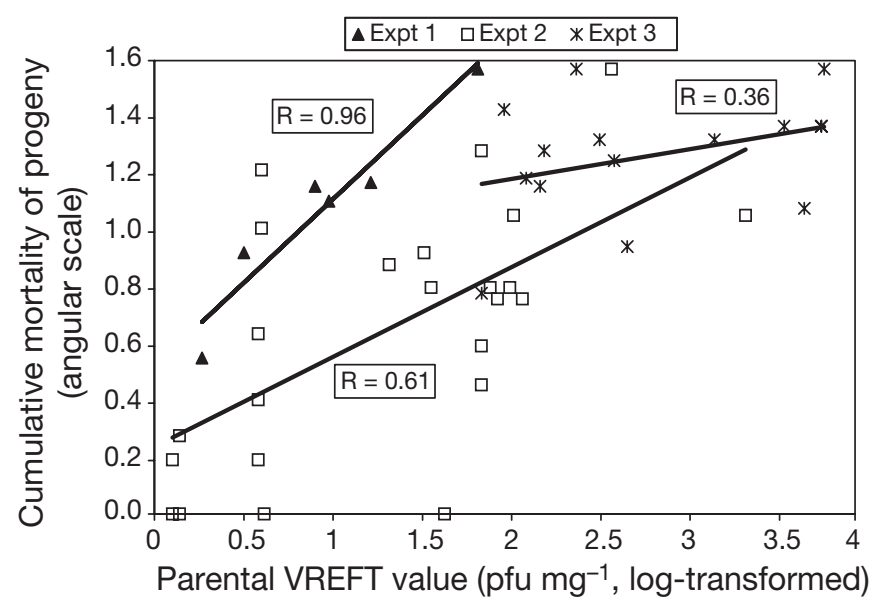

Fig. 3. Transformed mortality of progeny after waterborne VHSH challenge on the parental transformed VREFT values (angular transformation for mortality, logarithmic transformation for VREFT values; parental VREFT values are mid-parent values in Expt 1, maximum mid-parent values in Expt 2 and maximum male values in Expt 3). Coefficients of regression and p-values: $b=0.60$ and $p<0.002$ in Expt $1 ; b=0.31$ and $p<0.001$ in Expt $2 ; b=0.11$ and $p<0.19$ in Expt 3 not show any differences in the contributions of the 2 types of parents.

On the whole, highly resistant progeny (mortality $<10 \%$, angular transformed values $<0.32$ ) were obtained only when both parents exhibited very low

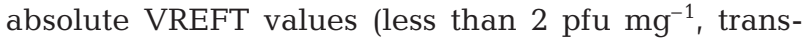
formed values $<0.3$ ), i.e. when fins were almost totally refractory to in vitro viral replication.

\section{DISCUSSION}

\section{Correlations between repeated measures of VREFT}

Our results indicate that under the conditions of the survey (fish kept under 'standard' farm conditions), correlations between the VREFT individual values recorded at different dates were moderate and that some individuals can even exhibit totally opposite values at successive samplings: from less than 10 pfu $\mathrm{mg}^{-1}$, which would classify them as fairly resistant, to more than $1000 \mathrm{pfu} \mathrm{mg}^{-1}$, a value associated with high susceptibility.

The portal of entry of VHSV has been the object of numerous studies that first focused on gills (de Kinkelin et al. 1979, Chilmonczyk 1980, Neukirch 1984, Konrad et al. 1989) and later on the epidermis (Yamamoto et al. 1992, Dorson \& Torhy 1993a, Estepa et al. 1993).

How the virus reaches the cells in which it first replicates is not known, but this event is likely a key step in the infection process. We have verified that processing fins as described here (infection in vitro after clipping from non-infected fish) gave results similar to those obtained when trout were infected by the water route, thoroughly 'rinsed' in flowing water with the fins sampled soon afterwards, placed in culture medium for $3 \mathrm{~d}$ and processed as described in 'Materials and methods' for the measure of viral replication. The success of virus penetration and growth in epidermal cells obviously depends on the quality of both the mucus 'barrier' and the status of cells including the presence of receptors, in this case fibronectin as demonstrated by Béarzotti et al. (1999). In farming conditions, many factors may affect epidermis cells and mucus production $(\mathrm{pH}$, ammonia, suspended matter, bacteria and parasites, biting, handling). It can be assumed that any factor detrimental to superficial cells (affecting cell receptors or cell metabolism) at the time of sampling impedes virus production during the in vitro assay. The result of the test (no virus replication) is then an artefact that leads to the identification of 'false' resistant fish. The risk of detecting 'false' resistant individuals when using VREFT values as a predictive trait was already emphasised by Quillet et al. (2001). Our present results indicate that repeated measurements may 
partly overcome the problem, provided that only the maximum value is retained in classifying individuals.

\section{VREFT values as a predictor of resistance}

The aim of the study was to test the merit of VREFT values in selecting individual brood fish to produce progeny of known resistance to VHSV for experimental purposes. Although high susceptibility to the virus is the most usual state in commercial strains (around 80-90\% mortality after challenge; Henryon et al. 2002, 2005, this study), obtaining totally susceptible groups (100\% mortality) would be useful, as it would reduce the within-group variability to host response and be advantageous in several experimental situations (e.g. test of vaccine efficiency, study of resistance induced after gene transfer, progeny testing of individual breeders). Yet, the most challenging objective is to obtain totally resistant groups.

Our study provided encouraging results on how to select experimental groups with extreme phenotypes. A high correlation between VREFT values of parents and resistance of the progeny was evidenced in Expts 1 and 2 . The relationship was extremely tight in Expt 1 $(\mathrm{R}=0.96)$, although it relied on a single record of VREFT for each breeder. A reason for this result may be the use of clonal progeny. Clones are expected to provide more precise estimates of the level of resistance, as challenge against the virus is repeated a number of times with the 'same' fish (individual genotype). Considering only clones in Expt 2, the correlation between mid-parent maximum VREFT values and mortality was not so high $(\mathrm{R}=0.73)$.

The results of Expt 3 were less conclusive, as there was no correlation between VREFT values of male parents and resistance of the progeny. The overall mortality was very high during that particular experimental season, as indicated by the mean mortality of the Sy group and of additional experimental groups challenged in the same year (results not shown). This situation may have impaired the expression of between-group variability in terms of resistance. Another reason for having recorded a weak correlation in this experiment is that all tested males exhibited very high VREFT values, which clearly foreshadowed the performance of the progeny. Having sampled Sy males with high VREFT values only may be a matter of bias in sampling, since Sy parents with

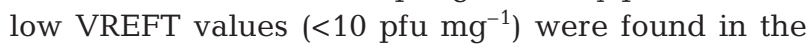
same strain in Expt 2 and contributed to the production of fully resistant progeny. The redistribution of genetic variance in haplo-diploid populations may also change the frequency distribution of VREFT in Gm fish when compared to Sy controls. As a matter of fact, only 2 of the 21 Sy parents examined exhibited low VREFT values, a lower frequency than in Gm parents (9 out of 17). However, larger-scale records are necessary to test this hypothesis.

In conclusion, selecting individual breeders within a wide range of VREFT values made it possible to produce progeny with extreme resistance/susceptibility to VHSV. This result was obtained without keeping breeders in a controlled environment, but rather maintaining them under 'standard' conditions (farm supplied with virus-free water flow). Repeated measurements of VREFT were required to score extreme individuals in a reliable manner. Breeders

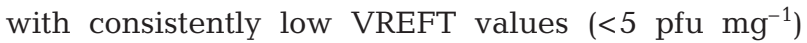
were good candidates to produce almost fully resistant progeny. They were found in both the control and homozygous populations, but it may be necessary to test a larger number of fish in an ordinary population to detect such individuals. With a view to producing pertinent biological material, a generation of mitogynogenesis prior to selection of breeders may bring additional benefits (production of clones). In contrast, pairing of parents that exhibit high VREFT values (>300 $\mathrm{pfu} \mathrm{mg}^{-1}$ ) resulted in highly susceptible progeny.

The transmission of resistance/susceptibility to progeny by parents selected on VREFT values are consistent with our previous findings (Quillet et al. 2001) and demonstrates that the 2 traits are governed by common genetic factors.

A comment is warranted on the potential merit of VREFT values as a predictor of the resistance of individual breeders for commercial selection purposes. Although estimates of heritability of resistance are promising (Dorson et al. 1995, Henryon et al. 2002, 2005), implementation of commercial selection for resistance to VHS is hampered by the cost of testing facilities. Reliable predictors of resistance would thus be most helpful in implementing indirect selection. VREFT appears to be a promising candidate. Nevertheless, more investigations are needed to confirm its predictive value under a range of field conditions (i.e. distribution of the trait in commercial populations, response to various environmental conditions).

\section{Implications for studies of resistance mechanisms}

Regarding the comprehensive study of hostpathogen relationships, our findings provide new evidence that resistance to VHSV is related to and probably depends on characteristics of epidermal tissues. As stated earlier, the role of epidermal tissues in the penetration of viruses, along with or in place of gills, has been demonstrated with 2 rhabdoviruses (Yamamoto 
et al. 1992, Dorson \& Torhy 1993b, Harmache et al. 2006), but further investigations are needed to elucidate the role they play in resistance and to identify the underlying mechanisms.

Do superficial tissues play an active role in the initial steps of infection (multiplication or penetration of the virus into more internal tissues)? Do they send an alarm to internal lymphoid organs that are the effective defence actors, making it possible for them to respond earlier in resistant fish? Or are they only a passive reflection of the actual susceptibility/resistance of internal target organs?

Several observations support the first hypothesis of an effective role of superficial tissues. It is striking that complete resistance was obtained only from fish whose fins were almost totally refractory to the viral replication. A similar result was obtained in the study by Quillet et al. (2001), where groups exhibiting low mortality had a very low mean VREFT value as well as a narrow range of individual values (with one exception). Hence, superficial tissues would act in an 'all or nothing' manner, and the barrier should be 'impenetrable' to complete its protective role (i.e. no virus replication and/or penetration). The hypothesis that resistance relies on events occurring before the virus reaches the main target organs (kidney, spleen, blood vessels) is supported by the results of previous trials comparing intraperitoneal injection and waterborne challenge as a route of infection (Dorson \& Torhy 1993a, Quillet et al. 2007) in which it was observed that internal tissues alone do not grant resistance to fish identified as resistant after waterborne infection. Another argument supporting the hypothesis is that survivors not carrying antibodies have sometimes been recorded after waterborne challenge (M. Dorson unpubl. data), although this can also be attributed to the lack of antibody response of some individuals despite the fact they have been stimulated by the virus. When epidermal tissues support high viral replication and do not prevent virus penetration, the organism would thus be invaded very early with high viral rates (as when injected) overwhelming internal defences regardless of their actual potential.

Epidermal tissue may also send early alarm signals to internal organs. A precocious but limited production of interferon may occur in fin tissue, although it could not be detected (Dorson \& Torhy 1994). Leucocytes scattered throughout the epidermis may also produce other cytokines, which would be enough to stimulate effective lymphoid organs at the early steps of infection and protect the organism against viral invasion.

Finally, the epidermal tissue may be a step in a response process where both external and internal organs display a given level of susceptibility/resis- tance depending on individual genetic components. Under this assumption, efficient internal defences would take over from epidermal tissues that had allowed a limited viral penetration in the first steps of infection with cumulative effects resulting in survival (resistance) in some individuals. The fact that virus can be detected in the internal organs (anterior kidney, spleen, brain) of survivors after waterborne infection (de Kinkelin et al. 1979, Quillet et al. 2007) shows that resistance may occur even after virus penetration and involve internal defences. In a systematic survey of in vitro viral replication in several organs of VHSV susceptible or resistant groups of fish, Dorson \& Torhy (1993b) found that viral titres were lower in resistant groups for most of the tested organs, whether they were external (fins) or internal (anterior kidney, spleen). Although the relationship was not evaluated at the individual level, this observation supports the hypothesis that both external and internal organs are involved in host response to a pathogen. More than the anterior kidney, the spleen appears to be a potent virus-producing organ when infected in vitro, as well as the best interferon producer in susceptible fish when virus replication is high (Dorson \& Torhy 1994, M. Dorson unpubl. data).

More investigation is needed to elucidate the pathways and outcomes (survival or death) of the hostpathogen response. Comparison of susceptible and resistant groups will be an efficient tool to progress along this route. The VREFT test we have developed may help in obtaining such experimental material.

Acknowledgements. Under French penal and rural code, E.Q. and M.D. have personal authorisation from the French Agricultural Ministry to conduct animal experiments (authorisation nos. 78-67 and 32-57 respectively) and ensure that all procedures used in this experiment were in accordance with the national and European regulations on animal care. The authors thank the technical staff at the INRA experimental farm in Gournay-sur-Aronde and at the UEP unit (Jouy-enJosas) where the experimental challenges were performed.

\section{LITERATURE CITED}

Bandin I, Dopazo CP, Muiswinkel WB, Wiegertjes GF (1997) Quantitation of antibody secreting cells in high and low antibody responder inbred carp (Cyprinus carpio L.) strains. Fish Shellfish Immunol 7:487-501

Béarzotti M, Delmas B, Lamoureux A, Loustau AM, Chilmonczyk S, Brémont M (1999) Fish rhabdovirus cell entry is mediated by fibronectin. J Virol 73:7703-7709

Bernard D, Six A, Rigottier-Gois L, Messiaen S, Chilmonczyk S, Quillet E, Boudinot P, Benmansour A (2006). Phenotypic and functional similarity of gut intra epithelial and systemic T cells in a teleost fish. J Immunol 176:3942-3949

Bijma P, Arendonk JAM, Bovenhuis H (1997) Breeding value and variance component estimation from data containing 
inbred individuals: application to gynogenetic families in common carp (Cyprinus carpio L.). Genetics 145: 1243-1249

Bongers ABJ, Bovenhuis $\mathrm{H}$, Stokkom AC, Wiegertjes GF, Zandieh-Doulabi B, Komen J, Richter CJJ (1997) Distribution of genetic variance in gynogenetic or androgenetic families. Aquaculture 153:225-238

Boudinot P, Boubekeur S, Benmansour A (2001) Rhabdovirus infection induces public and private $\mathrm{T}$ cell responses in teleost fish. J Immunol 167:6202-6209

Chilmonczyk S (1980) Some aspects of trout gill structure in relation to Egtved virus infection and defence mechanisms. In: Ahne W (ed) Fish diseases. Springer-Verlag, Berlin, Heidelberg, New York, p 18-22

Cousin-Gerber M, Burger G, Boisseau C, Chevassus B (1989) Effect of methyltestosterone on sex differentiation and gonad morphogenesis in rainbow trout Oncorhynchus mykiss. Aquat Living Resour 2:225-230

De Kinkelin P (1988) Vaccination against haemorrhagic septicaemia. In: Ellis AE (ed) Fish vaccination. Academic Press, London, p 172-192

De Kinkelin P, Chilmonczyk S, Dorson M, Leberre M, Baudouy AM (1979) Some pathogenic facets of rhabdoviral infection of salmonid fish. In: Bachmann PA (ed) Proc 4th Munich Symp Microbiol on Mechanisms of Viral Pathogenesis and Virulence, WHO, Munich, p 357-375

Diter A, Quillet E, Chourrout D (1993) Suppression of first egg mitosis induced by heat shocks in the rainbow trout. J Fish Biol 42:777-786

Dorson M, Torhy C (1993a) Viral haemorrhagic septicaemia virus replication in external tissue excised from rainbow trout, Oncorhynchus mykiss (Walbaum), and hybrids of different susceptibilities. J Fish Dis 16:403-408

Dorson M, Torhy C (1993b) Viral haemorrhagic septicaemia virus replication in organs from rainbow trout and hybrids of different susceptibilities. EAFP 6th Conf, Brest, 5-10 Sept (Abstract)

Dorson M, Torhy C (1994) Viral haemorrhagic septicaemia virus replication and interferon production in organs excised from resistant and susceptible trout. Int Symp Aquat Anim Health, Seattle, WA, 4-8 Sept (Abstract)

Dorson M, Quillet E, Hollebecq MG, Torhy C, Chevassus B (1995) Selection of rainbow trout resistant to viral haemorrhagic septicaemia virus and transmission of resistance by gynogenesis. Vet Res 26:361-368

Estepa A, Frias D, Coll JM (1993) In vitro susceptibility of rainbow trout fin cells to viral haemorrhagic septicaemia virus. Dis Aquat Org 15:35-39

Harmache A, LeBerre M, Droineau S, Giovannini M, Brémont M (2006) Bioluminescence imaging of live infected salmonids reveals that the fin bases are the major portal of entry for Novirhabdovirus. J Virol 80:3655-3659

Henryon M, Jokumsen A, Berg P, Lund I, Pedersen PB, Olesen NJ, Slierendrecht WJ (2002) Genetic variation for growth rate, feed conversion efficiency, and disease resistance exists within a farmed population of rainbow trout. Aquaculture 209:59-76 (Erratum: Aquaculture 216: 387-388)

Henryon M, Berg P, Olesen N, Kjaer T, Slierendrecht W, Jokumsen A, Lund I (2005) Selective breeding provides an approach to increase resistance of rainbow trout (Oncorhynchus mykiss) to the diseases, enteric redmouth disease, rainbow trout fry syndrome, and viral haemorrhagic septicaemia. Aquaculture 250:621-636

Hollebecq MG, Faivre B, Bourmaud C, Michel C (1995) Spontaneous bactericidal and complement activities in serum of rainbow trout (Oncorhynchus mykiss) genetically selected for resistance or susceptibility to furunculosis. Fish Shellfish Immunol 5:407-426

Jensen MH (1965) Research on the virus of Egtved disease. Ann NY Acad Sci 126:422-426

Khoo SK, Ozaki A, Nakamura F, Arakawa T and 7 others (2004) Identification of a novel chromosomal region associated with infectious haematopoietic necrosis (IHN) resistance in rainbow trout Oncorhynchus mykiss. Fish Pathol (Gyobyo Kenkyu) 39:95-101

Konrad M, Weiland F, Enzmann PJ (1989) Immunohistological studies on the pathogenesis of viral haemorrhagic septicaemia (VHS) in rainbow trout. In: Lillehund K, Rosenthal $\mathrm{H}$ (eds) Fish health protection strategies. Federal Ministry foor Research and Technology, Hamburg, p 121-134

Lorenzen N, Lapatra SE, 2005. DNA vaccines for aquaculture fish. Rev Sci Tech Off Int Epizoot, 201-213

Michel C, Hollebecq MG (1999) Independence of phagocytic activity and susceptibility to furunculosis in families of rainbow trout (Oncorhynchus mykiss) genetically selected for differential resistance. Fish Shellfish Immunol 9:81-93

Neukirch M (1984) An experimental study of the entry and multiplication of viral haemorrhagic septicaemia virus in rainbow trout, Salmo gairdneri Richardson, after waterborne infection. J Fish Dis 7:231-234

Ozaki A, Sakamoto T, Khoo S, Nakamura K, Coimbra MRM, Akutsu T, Okamoto N (2001) Quantitative trait loci (QTLs) associated with resistance/susceptibility to infectious pancreatic necrosis virus (IPNV) in rainbow trout (Oncorhynchus mykiss). Mol Genet Genomics 265:23-31

Palti Y, Parsons JE, Thorgaard G (1999) Identification of candidate DNA markers associated with IHN virus resistance in backcrosses of rainbow (Oncorhynchus mykiss) and cutthroat trout (O. clarki). Aquaculture 173:81-94

Peltz G, Usuka J (2005) From mouse genetics to human therapeutics. Curr Opin Drug Discov Dev 8(2):253-261

Quillet E (1994) Survival, growth and reproductive traits of mitotic gynogenetic rainbow trout females. Aquaculture 123:223-236

Quillet E, Dorson M, Aubard G, Torhy C (2001) In vitro viral haemorrhagic septicaemia virus replication in excised fins of rainbow trout: correlation with resistance to waterborne challenge and genetic variation. Dis Aquat Org 45: 171-182

Quillet E, Dorson M, Le Guillou S, Benmansour A, Boudinot P (2007) Wide range of susceptibility in homozygous clones of rainbow trout. Fish Shellfish Immunol 22:510-519

Ristow S, Grabowski LD, Ostberg C, Robison B, Thorgaard GH (1998) Development of long-term cell lines from homozygous clones of rainbow trout. J Aquat Anim Health 10:75-82

Ristow SS, LaPatra SE, Dixon R, Pedrow CR, Shewmaker WD, Park J, Thorgaard GH (2000) Responses of cloned rainbow trout Oncorhynchus mykiss to an attenuated strain of infectious hematopoietic necrosis virus. Dis Aquat Org 42: 163-172

Røed KH, Fevolden SE, Fjalestad KT (2002) Disease resistance and immune characteristics in rainbow trout (Oncorhynchus mykiss) selected for lysozyme activity. Aquaculture 209:91-101

Slierendrecht WJ, Jensen LB, Horlyck V, Koch C (1993) Genetic polymorphism of complement component C3 in rainbow trout (Oncorhynchus mykiss) and resistance to viral haemorrhagic septicaemia. Fish Shellfish Immunol 3: 199-206

Slierendrecht WJ, Olesen NJ, Lorenzen N, Jorgensen PEV, Gottschau A, Koch C (1996) Genetics alloforms of rainbow trout (Oncorhynchus mykiss) complement component C3 
and resistance to viral haemorrhagic septicaemia virus under experimental conditions. Fish Shellfish Immunol 6: 235-237

Slierendrecht WJ, Olesen NJ, Juul-Madsen HR, Lorenzen N, Henryon M, Berg P, Sondergaard J, Koch C (2001) Rainbow trout offspring with different resistance to viral haemorrhagic septicaemia. Fish Shellfish Immunol 11:155-167

Trobridge GD, Lapatra SE, Kim CH, Leong JC (2000) Mx mRNA expression and RFLP analysis of rainbow trout Oncorhynchus mykiss genetic crosses selected for susceptibility or resistance to IHNV. Dis Aquat Org 40:1-7

Wiegertjes GF, Bongers ABJ, Voorthuis P, Zandieh-Doulabi B,

Editorial responsibility: Mark Crane,

Geelong, Victoria, Australia
Groeneveld A, Muiswinkel WB, Stet RJM (1996) Characterization of isogenic carp (Cyprinus carpio L.) lines with a genetically determined high or low antibody production. Anim Genet 27:313-319

Yamamoto T, Batts WN, Winton JR (1992) In vitro infection of salmonid epidermal tissues by infectious hematopoietic necrosis virus and viral haemorrhagic septicaemia virus $\mathrm{J}$ Aquat Anim Health 4:231-239

Zimmerman AM, Evenhuis JP, Thorgaard GH, Ristow SS (2004) A single major chromosomal region controls natural killer cell-like activity in rainbow trout. Immunogenetics 55:825-835

Submitted: June 7, 2006; Accepted: March 1, 2007 Proofs received from author(s): May 12, 2007 